BioLink, Vol. 5 (1) Agustus (2018) p-ISSN: 2356-458X e-ISSN: 2550-1305

DOI: http://dx.doi.org/10.31289/biolink.v5i1.1697

BioLink

Jurnal Biologi Lingkungan, Industri, Kesehatan

Available online http://ojs.uma.ac.id/index.php/biolink

\title{
KETEPATAN PEMBERIAN ANTIBIOTIK PADA PASIEN ISPA BAGIAN ATAS DI PUSKESMAS PEKAN LABUHAN MEDAN PADA BULAN JANUARI - JUNI 2017
}

\section{Accuracy of Antibiotics in Upper Respiratory Patients at Public Health Center Pekan Labuhan Medan in January - June 2017}

\author{
Eva Sartika Dasopang*, Atin Juniati \\ *Fakultas Farmasi, Universitas Tjut Nyak Dhien, Gg. Rasmi No.28, Sei Sikambing C. II, Medan \\ Helvetia, Kota Medan
}

*Corresponding author: E-mail: evasartikadasopang@yahoo.com

\begin{abstract}
Abstrak
Infeksi saluran pernapasan akut (ISPA) merupakan salah satu penyakit yang menyerang saluran utama pernapasan yaitu hidung, alveoli, andeksana, sinus, rongga telingga tengah dan pleura. Infeksi akut ialah suatu infeksi yang berlangsung sampai dengan batas waktu 14 hari. Penelitian ini bertujuan Untuk mengetahui ketepatan pemberian antibiotik pada pasien ISPA di Puskesmas Pekan Labuhan Medan sudah atau belum sesuai dengan pedoman pengobatan dasar di Puskesmas 2007. Metode yang digunakan dalam penelitian ini adalah metode cross sectional dan menggunakan pendekatan retrospektif, yaitu penelitian yang dilakukan dengan cara pendekatan observasi, pengumpulan data sekaligus pada satu waktu dan menggunakan data yang lalu. Dalam hal ini yang merupakan variabel bebas adalah umur pasien, jenis kelamin, lingkungan tempat tinggal, diagnosa, dan pemberian antibiotik, dan sebagai variabel terikat adalah ketepatan pemberian antibiotik pada pasien ISPA di Puskesmas Pekan Labuhan Medan. Pemberian antibiotik berdasarkan diagnosis pasien ISPA bagian atas di Puskesmas Pekan Labuhan Medan sebesar 93,2\% ada yang belum sesuai dengan pedoman pengobatan dasar di Puskesmas 2007 yang ditetapkan. Ketidaksesuaian itu meliputi jenis antibiotik dan kesesuaian indikasi pemberiannya.
\end{abstract}

Kata Kunci: Pernafasan, Karakteristik Pasien, Cross sectional, Antibiotik

\begin{abstract}
Acute respiratory tract infection is one of the diseases that attack the main chanel of the raspiration of the nose, alveoli, andeksana, sinus, middle ear cavity and pleura. Acute infection is an infection that lasts for a 14 day time limit. This study aims to determine the accuracy of antibiotics in patients with URI in public health center Pekan Labuhan Medan is in accordance or not in accordance with the basic treatment guidelines in public health center 2007. Administration of antibiotics based on diagnosis of upper respiratory infection patients at Public Health Center Pekan Labuhan Medan of 93,2\% there is not yet according to basic treatment guidance in Public Health Center 2007 which is set. Such discrepancies include the type of antibiotics and the suitability of the indication of administration.
\end{abstract}

Keywords: respiratory, patient charactristics, crossectional, antibiotic

How to Cite: Dasopang, E.S. dan Juniati, A, (2018), Ketepatan Pemberian Antibiotik pada Pasien ISPA Bagian Atas di Puskesmas Pekan Labuhan Medan pada Bulan Januari-Juni 2017, BioLink. Vol.5 (1): Hal. $11-21$ 
Eva Sartika Dasopang \& Atin Juniati, Ketepatan Pemberian Antibiotik pada Pasien ISPA Bagian

PENDAHULUAN

Puskesmas (pusat kesehatan masyarakat) adalah suatu organisasi kesehatan fungsional yang merupakan pusat pengembangan kesehatan masyarakat yang juga membina peran serta masyarakat disamping memberikan pelayanan secara menyeluruh dan terpadu kepada masyarakat diwilayah kerjanya dalam bentuk kegiatan pokok (Effendi, 2009).

Infeksi saluran pernapasan akut (ISPA) merupakan infeksi saluran pernapasan atau yang lebih sering disebut dengan ISPA merupakan salah satu penyakit yang menyerang saluran utama pernapasan yaitu hidung, alveoli, andeksana, sinus, rongga telingga tengah, dan pleura.

Antibiotika adalah zat yang dihasilkan oleh suatu mikroorganisme hidup terutama jamur yang dapat menghambat atau dapat membasmi mikroba jenis lain.

Secara umum peresepan sering suboptimal, tidak hanya di Negara berkembang namun juga di Negara maju. Meluasnya penggunaan antibiotika yang tidak tepat merupakan isu besar dalam kesehatan masyarakat dan keamanan pasien. Penggunaan antibiotika yang tidak tepat dapat menimbulkan berbagai masalah, diantaranya penggobatan akan lebih mahal, efek samping lebih toksik,

meluasnya resistensi, dan timbulnya kejadian suprainfeksi yang sulit diobati (Gunawan, dkk., 2007).

Upaya untuk memaksimalkan penggunaan antibiotik yang rasional merupakan salah satu tanggung jawab penting dari pelayanan farmasi. Hal yang dapat dilakukan diantaranya adalah menentapkan dan melaksanakan pekerjaan secara kontinu mengkaji serta menyempurnakan untuk terapi antibiotika, program ini dilaksanakan oleh farmasi bersama staf medis lainnya. Ketepatan pemberian antibiotika pada pasien ISPA merupakan salah satu bentuk tanggung jawab farmasis di lingkungan puskesmas dalam rangka mempromosikan penggunaan antibiotik yang rasional (Ansel, 2008).

\section{METODE PENELITIAN}

Metode penelitian yang digunakan dalam penelitian ini adalah metode cross sectional dan menggunakan pendekatan retrospektif, yaitu penelitian yang dilakukan dengan cara pendekatan observasi, pengumpulan data sekaligus pada satu waktu dan menggunakan data yang lalu (Notoatmodjo, 2010).

Bahan dan sumber data dari penelitian ini diperoleh dari rekam medik pasien ISPA dipuskesmas Pekan Labuhan Medan. 
Penelitian dilaksanakan di

Puskesmas Pekan Labuhan Medan dan waktu penelitian bulan Juli 2017 dengan pengamatan retrospektif yaitu data pasien ISPA pada bulan Januari-Juni 2017.

Populasi dalam penelitian ini adalah semua pasien ISPA bagian atas yang terdaftar pada register dan rekam medis pasien ISPA bagian atas yang berkunjung ke poli umum Puskesmas Pekan Labuhan Medan sepanjang periode bulan JanuariJuni 2017. Populasi yang terdapat di puskesmas Pekan Labuhan Medan sebanyak 563 orang.

Sampel pada penelitian ini dilakukan secara total sampling dengan kriteria sampel yang diikutsertakan dalam penelitian ini seluruh pasien yang terdiagnosis ISPA bagian atas tanpa komplikasi yang rawat jalan di Puskesmas Pekan Labuhan Medan sepanjang periode bulan Januari-Juni 2017.

Kriteria inklusi pada penelitian ini adalah rekam medis pasien yang terdiagnosa ISPA bagian atas yang datang ke poli umum Puskesmas Pekan Labuhan Medan sepanjang periode bulan JanuariJuni 2017.

\section{Prosedur kerja}

Mencatat nomor rekam medis pasien yang terdiagnosis ISPA dari register harian di puskesmas Pekan Labuhan Medan.
Mencatat data seperti nama, usia, jenis kelamin, tempat tinggal, gejala, tanda klinis, dan penggobatan dari rekam medis tersebut.

Analisis data kemudian dilanjutkan dengan cara deskriptif menggunakan program SPSS

\section{Analisa Data}

Data yang diperoleh diolah dengan menggunakan program SPSS versi 22,0 for windows, disajikan dalam bentuk tabel

\section{HASIL DAN PEMBAHASAN}

Dari hasil penelitian yang diteliti diperoleh 563 rekam medik yang telah memenuhi kriteria inklusi, didapatkan karakteristik subjek penelitian berdasarkan kelompok umur, jenis kelamin, tempat tinggal, diagnosis, dan pemberian antibiotik. 
Eva Sartika Dasopang \& Atin Juniati, Ketepatan Pemberian Antibiotik pada Pasien ISPA Bagian Tabel 1 Karakteristik subjek penelitian berdasarkan kelompok umur

\begin{tabular}{cccc}
\hline No & Kelompok Umur & Frekuensi & Persentase \\
\hline 1 & 0-5 tahun & 161 & $28,6 \%$ \\
2 & 6-11 tahun & 90 & $16,0 \%$ \\
3 & 12-16 tahun & 50 & $8,9 \%$ \\
4 & 17-25 tahun & 48 & $8,5 \%$ \\
5 & 26-35 tahun & 55 & $9,8 \%$ \\
6 & 36-45 tahun & 40 & $7,1 \%$ \\
7 & 46-55 tahun & 64 & $11,4 \%$ \\
8 & $>56$ tahun & 55 & $9,8 \%$ \\
& Total & $\mathbf{5 6 3}$ & $\mathbf{1 0 0 \%}$ \\
\hline Berdasarkan & tabel 1 diatas, & kelompok umur & $56-65$ tahun sebesar
\end{tabular}
didapatkan data karakteristik subjek 9,8\%, kelompok umur 12-16 tahun 8,9\%, penelitian kelompok umur yang paling kelompok umur 17-25 tahun 8,5\%, dan tinggi mengalami ISPA adalah usia $<5$ kelompok umur 36-45 tahun merupakan tahun yaitu sebesar 28,6\%, disusul oleh kelompok umur paling rendah mengalami kelompok umur 5-11 tahun sebesar ISPA yaitu sebesar 7,1\%. 16,0\%, kelompok umur 46-55 tahun sebesar 11,4\%, kelompok umur 26-35 dan Tabel 2 Karakteristik subjek penelitian berdasarkan jenis kelamin

\begin{tabular}{cccc}
\hline No & Jenis Kelamin & Frekuensi & Persentase \\
\hline 1 & Perempuan & 291 & $51,7 \%$ \\
2 & Laki-Laki & 272 & $48,3 \%$ \\
& Total & $\mathbf{5 6 3}$ & $\mathbf{1 0 0 \%}$ \\
\hline Berdasarkan tabel 2 diatas, diperoleh & Pekan & Labuhan & Medan yaitu pasien
\end{tabular}
data karakteristik berdasarkan jenis perempuan yang menderita ISPA kelamin yang diambil dari data sekunder sebanyak 291 pasien dengan persentasi register harian dan rekam medis pada 51,7\%, dan pasien laki-laki sebanyak 272 bulan Januari-Juni 2017 di Puskesmas pasien dengan pesentase sebesar 48,3\%.

Tabel 3 Karakteristik subjek penelitian berdasarkan lingkungan tempat tinggal.

\begin{tabular}{clcc}
\hline No & Lingkungan & Frekuensi & Persentase \\
\hline 1 & I Pekan Labuhan & 136 & $24,2 \%$ \\
2 & II Pekan Labuhan & 148 & $26,3 \%$ \\
3 & III Pekan Labuhan & 239 & $42,5 \%$ \\
4 & Martubung & 13 & $2,3 \%$ \\
5 & Kampung Nelayan & 9 & $1,6 \%$ \\
6 & Sungai Mati & 11 & $2,0 \%$ \\
7 & Belawan & 7 & $1,2 \%$ \\
& Total & $\mathbf{5 6 3}$ & $\mathbf{1 0 0 \%}$ \\
\hline
\end{tabular}


Berdasarkan tabel 3 diatas, diperoleh data penelitian karakteristik berdasarkan lingkungan tempat tinggal pasien yang didapatkan dari data sekunder berdasarkan register harian dan rekam medis pasien ISPA bagian atas yang datang ke Puskesmas Pekan Labuhan Medan pada bulan Januari-Juni 2017 didapatkan, lingkungan dengan

persentase pasien ISPA bagian atas yang paling tinggi adalah lingkungan III Pekan Labuhan sebesar 42,5\%, diikuti oleh lingkungan II Pekan Labuhan sebesar 26,3\%, lingkungan I Pekan Labuhan sebesar 24,2\%, Martubung sebesar 2,3\%, Sungai Mati 2,0\%, Kampung Nelayan 1,6\%, dan Belawan sebesar 1,2\%.

Tabel 4. Gambaran diagnosis

\begin{tabular}{clcc}
\hline No & \multicolumn{1}{c}{ Diagnosis } & Frekuensi & Persentase \\
\hline 1 & Commond Cold & 485 & $86,1 \%$ \\
2 & Rinitis & 8 & $1,4 \%$ \\
3 & Faringitis & 27 & $4,8 \%$ \\
4 & Sinusitis & 8 & $1,4 \%$ \\
5 & Tonsilitis & 35 & $6,2 \%$ \\
& Total & $\mathbf{5 6 3}$ & $\mathbf{1 0 0 \%}$ \\
\hline
\end{tabular}

Berdasarkan tabel 4 diatas, diperoleh persentase sebesar 6,2\%, faringitis data gambaran diagnosis ISPA bagian atas sebanyak 27 pasien dengan persentase di Puskesmas Pekan Labuhan Medan, sebesar 4,8\%, rinitis sebanyak 8 pasien diklasifikasikan dengan sebaran common dengan persentase sebesar 1,4\%, dan cold sebanyak 485 pasien dengan sinusitis dengan 8 pasien dan persentase persentase sebesar 86,1\%, diikuti yang sama yaitu 1,4\%.

tonsillitis sebanyak 35 pasien dengan

Tabel 5 Gambaran pemberian antibiotik pada pasien ISPA bagian atas

\begin{tabular}{cccc}
\hline No & Jenis Antibiotik & Frekuensi & Persentase \\
\hline 1 & Amoksisilin & 300 & $53,3 \%$ \\
2 & Siprofloksasin & 137 & $24,3 \%$ \\
3 & Kotrimoksasol & 86 & $15,3 \%$ \\
4 & Tidak Diberikan & 40 & $7,1 \%$ \\
& Total & $\mathbf{5 6 3}$ & $\mathbf{1 0 0 \%}$ \\
\hline
\end{tabular}

Pada tabel 5 diatas, didapatkan data sebesar 15,3\%, serta terdapat pasien ISPA berdasarkan rekam medis pasien yang yang tidak diberikan antibiotik sebesar terdiagnosis ISPA bagian atas bahwa 7,1\%.

gambaran pemberian antibiotik amoksisilin pada urutan pertama yaitu dengan persentase 53,3\%, antibiotik lain juga diberikan seperti siprofloksasin yang berada di urutan kedua dengan persentase sebesar $24,3 \%$, diikuti oleh kotrimoksazol 
Eva Sartika Dasopang \& Atin Juniati, Ketepatan Pemberian Antibiotik pada Pasien ISPA Bagian

Tabel 6 Gambaran pemberian antibiotik berdasarkan diagnosis

\begin{tabular}{|c|c|c|c|c|}
\hline \multirow[t]{2}{*}{ No } & \multirow{2}{*}{ Diagnosis } & \multicolumn{2}{|c|}{ Pemberian Antibiotik } & \multirow{2}{*}{ Total } \\
\hline & & Ya & Tidak & \\
\hline 1 & Common Cold & $\begin{array}{c}452 \\
(93,2 \%)\end{array}$ & $\begin{array}{c}33 \\
(6,8 \%)\end{array}$ & 485 \\
\hline 2 & Rinitis & $\begin{array}{c}6 \\
(75 \%)\end{array}$ & $\begin{array}{c}2 \\
(25 \%)\end{array}$ & 8 \\
\hline 3 & Faringitis & $\begin{array}{c}25 \\
(92,6 \%)\end{array}$ & $\begin{array}{c}2 \\
(7,4 \%)\end{array}$ & 27 \\
\hline 4 & Sinusitis & $\begin{array}{c}7 \\
(87,5 \%)\end{array}$ & $\begin{array}{c}1 \\
(12,5 \%)\end{array}$ & 8 \\
\hline 5 & Tonsilitis & $\begin{array}{c}33 \\
(94,3 \%)\end{array}$ & $\begin{array}{c}2 \\
(5,7 \%)\end{array}$ & 35 \\
\hline & Total & & & 563 \\
\hline
\end{tabular}

Berdasarkan tabel 6 diatas, sebanyak 25 pasien dengan persentase didapatkan data gambaran pemberian sebesar 92,6\%, pada sinusitis sebanyak 7 antibiotik berdasarkan diagnosis pasien dengan persentase sebesar 87,5\%, terbanyak yaitu common cold yang dan yang terakhir pada kasus tonsillitis diberikan antibiotik sebanyak 452 pasien sebanyak 33 pasien dengan persentase dengan persentase sebesar 93,2\%, pada sebesar 94,3\%.

kasus rinitis sebanyak 6 pasien dengan persentase sebesar $75 \%$, pada faringitis

Tabel 7 Gambaran pemberian jenis antibiotik berdasarkan diagnosis

\begin{tabular}{|c|c|c|c|c|c|c|c|c|c|}
\hline \multirow{3}{*}{$\begin{array}{c}\text { Diagnosis } \\
\text { Commond cold }\end{array}$} & \multicolumn{9}{|c|}{ Pemberian antibiotik } \\
\hline & \multicolumn{2}{|c|}{ amoksisilin } & \multicolumn{2}{|c|}{ Siprofloksasin } & \multicolumn{2}{|c|}{ Kotrimoksasol } & \multicolumn{2}{|c|}{$\begin{array}{c}\text { Tidak } \\
\text { diberikan }\end{array}$} & \multirow{2}{*}{$\begin{array}{c}\text { Jumlah } \\
485\end{array}$} \\
\hline & 237 & $(48,9 \%)$ & 99 & $(20,4 \%)$ & 118 & $(24,3 \%)$ & 31 & $(6,4 \%)$ & \\
\hline Rinitis & 5 & $(62,5 \%)$ & 1 & $(12,5 \%)$ & 0 & $(0 \%)$ & 2 & $(25,0 \%)$ & 8 \\
\hline Faringitis & 13 & $(48,1 \%)$ & 9 & $(33,3 \%)$ & 3 & $(11,1 \%)$ & 2 & $(7,4 \%)$ & 27 \\
\hline Sinusitis & 3 & $(37,5 \%)$ & 4 & $(50,0 \%)$ & 0 & $(0 \%)$ & 1 & $(12,5 \%)$ & 8 \\
\hline Tonsilitis & 23 & $(65,7 \%)$ & 6 & $(17,1 \%)$ & 4 & $(11,4 \%)$ & 2 & $(5,7 \%)$ & 35 \\
\hline Total & \multicolumn{9}{|c|}{563} \\
\hline
\end{tabular}

Berdasarkan tabel 7 diatas, $48,1 \%$, pada pasien sinusitis paling banyak diperoleh data gambaran pemberian jenis diberikan antibiotik siprofloksasin sebesar antibiotik berdasarkan diagnosis yaitu 50\%, dan pada tonsillitis paling banyak pada pasien common cold paling banyak diberikan antibiotik amoksisilin sebesar diberikan antibiotik amoksisilin yaitu 65,7\%. sebesar 48,9\%, pada pasien rinitis paling banyak diberiakan antibiotik amoksisilin sebesar 62,5\%, pada pasien yang terdiagnosa faringitis paling banyak diberikan antibiotik amoksisilin sebesar 
Tabel 8 Gambaran ketepatan pemberian antibiotik berdasarkan diagnosis

\begin{tabular}{lccc}
\hline \multicolumn{1}{c}{ Diagnosis } & \multicolumn{2}{c}{ Ketepatan Pemberian Antibiotik } & Total \\
\cline { 2 - 3 } & \multicolumn{1}{c}{ Tepat } & Tidak Tepat & \\
\hline Common cold & $33(6,8 \%)$ & $452(93,2 \%)$ & 485 \\
Rinitis & $2(28,6 \%)$ & $5(71,4 \%)$ & 7 \\
Faringitis & $16(59,2 \%)$ & $11(40,7 \%)$ & 27 \\
Sinusitis & $3(37,5 \%)$ & $5(62,5 \%)$ & 8 \\
Tonsilitis & $24(66,7 \%)$ & $12(33,4 \%)$ & 36 \\
\multicolumn{1}{c}{ Total } & & $\mathbf{5 6 3}$ & \\
\hline
\end{tabular}

Berdasarkan tabel 8 diatas, kelompok umur paling rendah mengalami didapatkan data gambaran ketepatan ISPA yaitu sebesar 7,1\%.

pemberian antibiotik berdasarkan diagnosis pada pasien common cold sebesar 6,8\% yang tepat dan 93,2\% yang tidak tepat, pada pasien rinitis didapatkan data $28,6 \%$ yang tepat dan $71,4 \%$ yang tidak tepat, pada pasien faringitis 59,2\% yang tepat dan $40,7 \%$ yang tidak tepat, sedangkan pada pasien sinusitis didapatkan 37,5\% tepat dan 62,5\% tidak tepat dan pasien tonsillitis didapatkan persentase sebesar $66,7 \%$ tepat dan $33,4 \%$ tidak tepat.

Dilihat dari sebaran kelompok umur pasien ISPA yang datang ke Puskesmas Pekan Labuhan Medan, kelompok umur yang paling tinggi mengalami ISPA adalah usia $<5$ tahun yaitu sebesar $28,6 \%$ disusul oleh kelompok umur 5-11 tahun sebesar $16 \%$, kelompok umur 46-55 tahun sebesar 11,4 \%, kelompok umur 26-35 tahun dan kelompok umur 56-65 tahun sebesar 9,8\%, kelompok umur 12-16 tahun sebesar 8,9\%, dan kelompok umur 17-25 tahun sebesar 8,5\%, sedangkan kelompok umur 36-45 tahun merupakan
Infeksi saluran pernafasan akut (ISPA) merupakan suatu penyakit yang sering terjadi pada semua golongan umur, terutama pada balita dan anak. Sejumlah studi yang besar menunjukkan bahwa insiden penyakit pernafasan oleh virus melonjak pada bayi dan usia dini anakanak. ISPA dapat menyerang semua tingkat usia, terutama pada usia kurang dari 5 tahun karena daya tahan tubuh balita lebih rendah dari orang dewasa sehingga mudah menderita ISPA. Umur diduga terkait dengan sistem kekebalan tubuhnya belum sempurna, sehingga masih rentan terhadap berbagai penyakit infeksi.

Berdasarkan hasil penelitian yg didapatkan persentase pasien ISPA lakilaki yang berkunjung ke Puskesmas Pekan Labuhan Medan sebesar 48,3\% dan pasien ISPA perempuan yang berkunjung sebesar $51,7 \%$ hal ini sejalan dengan penelitian (Hidayati dan Rachmawati, 2008).

Berdasarkan hasil penelitian yang didapatkan, lingkungan dengan persentase 
Eva Sartika Dasopang \& Atin Juniati, Ketepatan Pemberian Antibiotik pada Pasien ISPA Bagian

ISPA bagian atas paling tinggi adalah lingkungan III Pekan Labuhan sebesar 42,5\%, diikuti oleh lingkungan II Pekan Labuhan sebesar 26,3\%, lingkungan I Pekan Labuhan sebesar 24,2\%, Martubung sebesar 2,3\%, Sungai Mati 2,0\%, Kampung Nelayan 1,6\%, dan Belawan sebesar 1,2\%. Lingkungan III Pekan Labuhan Medan merupakan lingkungan dengan kasus persentase pasien ISPA bagian atas yang paling tinggi diwilayah kerja puskesmas Pekan Labuhan Medan. Karena daerah tersebut merupakan daerah yang mempunyai tingkat polusi udara yang cukup tinggi, dekat dengan Kawasan Industri Medan (KIM). Sehingga angka kejadian ISPA cukup tinggi didaerah tersebut yaitu sekitar $42,5 \%$.

Mengacu pada data yang didapatkan, diagnosis ISPA bagian atas diklasifikasikan dengan sebaran terbesar common cold sebesar $86,1 \%$, tonsillitis sebesar 6,2\%, faringitis sebesar 4,8\%, dan diagnosis yang terendah adalah rinitis dan sinusitis yang masing-masing sebesar 1,4\%. Menurut World Health Organization (WHO) common cold merupakan salah satu penyakit infeksi yang sering terjadi. WHO memperkirakan insidensi ISPA di Negara berkembang dengan angka kematian balita diatas 40 per 1000 kelahiran hidup adalah $15-20 \%$ pertahun pada golongan usia bayi dan balita.
Berdasarkan diagnosis, pada pasien yang terdiagnosis common cold diberikan antibiotik yang terbanyak yaitu amoksisilin sebesar 48,9\%. Antibiotik lain yang diberikan berupa siprofloksasin dan kotrimoksazol, masing-masing sebesar 20,4\% dan 24,3\%, Sisanya tidak diberikan antibiotik sebesar 6,4\%. Penggunaan antibiotik pada pasien common cold, baik amoksisilin, siprifloksasin, kotrimoksazol yang berjumlah total sebanyak 93,6\% tidak sesuai dengan pedoman pengobatan dasar di Puskesmas tahun 2007, dimana dikatakan pada common cold tidak diberikan antibiotik karena pada common cold etiologi terbanyak disebabkan oleh virus. Pada common cold, terapi diutamakan dengan menggunakan obat simptomatis sesuai dengan keluhan yang dialami oleh pasien. Selain itu common cold juga akan sembuh dengan sendirinya setelah 3-5 hari. Sehingga pemberian antibiotik pada pasien common cold yang berjumlah 93,6\% tidak memenuhi pedoman berdasarkan pedoman pengobatan dasar di Puskesmas tahun 2007.

Pada pasien yang terdiagnosis sebagai rinitis, antibiotik terbanyak yang diberikan yaitu amoksisilin sebesar 62,5\% (5 dari 8 pasien). Antibiotik lain yang diberikan yaitu siprofloksasin 12,5\% (1 dari 8 pasien) dan selebihnya tidak diberikan yaitu 25,0\% (2 dari 8 pasien). 
Sehingga jumlah keseluruhan pasien rinitis yang diberikan antibiotik sebesar 75\% (6 pasien). Berdasarkan pedoman pengobatan dasar di Puskesmas tahun 2007, penyakit rinitis disebabkan oleh suatu reaksi alergi terhadap serbuk sari yang terdapat dalam udara. Sehingga dalam hal ini tidak dipergunakan antibiotik dalam tatalaksana penyakit rinitis. Pengobatan utama dalam rinitis yaitu dengan menggunakan obat simptomatis berupa antihistamin dan kadang dipergunakan pula dekongestan untuk melegakan hidung. Sehingga berdasarkan data penelitian yang diperoleh hanya sebesar 25\% (2 pasien) yang memenuhi pedoman pengobatan dasar di Puskesmas 2007 yaitu tidak diberikan antibiotik. Sebagian besar dari pasien yaitu sebanyak $75 \%$ tidak memenuhi pedoman penatalaksanaan rinitis berdasarkan pedoman pengobatan dasar di Puskesmas tahun 2007, karena diberikan antibiotik.

Pasien yang terdiagnosis faringitis terbanyak diberikan antibiotik berupa amoksisilin, yaitu sebesar 48,1\% (13 pasien dari 27 pasien faringitis). Sisanya diberikan antibiotik berupa siprofloksasin dan kotrimoksazol, masing-masing sebesar $33,3 \%$ dan $11,1 \%$, dan pasien yang tidak diberikan antibiotik sebesar 7,4\%. Sehingga jumlah keseluruhan pasien faringitis yang diberikan antibiotik adalah
25 pasien (92,5\%). Penggunaan antibiotik pada faringitis didasarkan pada infeksi bakteri atau virus. Antibiotik yang diberikan pada penderita faringitis berupa kotrimoksazol 2 tablet $2 \times$ sehari selama 5 hari dan amoksisilin $500 \mathrm{mg} 3$ x sehari selama 5 hari (berdasarkan pedoman pengobatan dasar di Puskesmas 2007). Dari hasil penelitian ditemukan adanya pemberian antibiotik siprofloksasin sebesar 33,3\% kepada pasien faringitis. Hal tersebut tidak sesuai dengan pedoman pengobatan dasar di Puskesmas 2007. Adanya pemberian antibiotika tersebut dikarenakan kurangnya pengadaan antibiotika yg seharusnya diberikan untuk pasien faringitis.

Pada data yang diperoleh, pasien yang terdiagnosis sebagai sinusitis terbanyak diberikan antibiotik berupa siprofloksasin sebesar 50\%, amoksisilin $37,5 \%$, dan yang tidak diberi antibiotik sebesar 12,5\%. Pada penyakit sinusitis, terapi yang diberikan berupa dekongestan untuk mengurangi penyumbatan, obat pereda nyeri unuk mengurangi rasa nyeri, antibiotik (apabila disebabkan oleh bakteri). Penentuan infeksi bakteri ini mempergunakan pendekatan klinis yang meliputi gejala: gejala menetap lebih dari 10 hari, demam yang tinggi $>39^{\circ} \mathrm{C}$, secret nasal, serta pemburukan gejala. Dari hasil penelitian yang diperoleh adanya pasien sinusitis yang tidak diberikan antibiotik 
Eva Sartika Dasopang \& Atin Juniati, Ketepatan Pemberian Antibiotik pada Pasien ISPA Bagian

sebesar $12,5 \%$ dan diberikan antibiotik siprofloksasin sebesar 50\%. Pada pedoman pengobatan dasar di Puskesmas 2007 terapi awal pengobatan sinusitis diberikan antibiotik amoksisilin atau kotrimoksazol. Sehingga pada kasus sinusitis di Puskesmas Pekan Labuhan Medan ditemukan adanya pengobatan yang belum sesuai berdasarkan pedoman tersebut.

Pada pasien tonsillitis, antibiotik terbanyak yang diberikan berupa amoksisilin sebesar 65,7\%, siprofloksasin $17,1 \%$, kotrimoksazol 11,4\%, dan sisanya tidak diberikan antibiotik yaitu sebesar 5,7\%. Sehingga jumlah keseluruhan pasien tonsillitis yang diberikan antibiotik adalah 94,2\%. Menurut pedoman pengobatan dasar di Puskesmas 2007, jika terdiagnosis sebagai tonsillitis yang disebabkan oleh bakteri, maka pemberian antibiotik berupa eritromisin $500 \mathrm{mg} 3$ x sehari atau amoksisilin $500 \mathrm{mg}$ tiap 8 jam sekali selama 7 hari. Dari hasil penelitian didapatkan pasien tonsillitis yang tidak diberikan antibiotik sebesar 5,7\%. Kemungkinan hal tersebut terjadi karena penyebab tonsillitis berupa virus, maka akan sembuh dengan sendirinya dalam 57 hari. Jadi pengobatan tonsillitis di Puskesmas Pekan Labuhan Medan sudah sesuai dengan pedoman pengobatan dasar di Puskesmas 2007.

\section{SIMPULAN}

Berdasarkan hasil penelitian ini maka dapat di simpulkan bahwa gambaran pemberian antibiotik pada pasien ISPA di wilayah kerja Puskesmas Pekan Labuhan Medan masih tinggi, yang terbanyak digunakan antibiotik amoksisilin, siprofloksasin, kotrimoksasol, dan pemberian antibiotik berdasarkan diagnosis pasien ISPA bagian atas di wilayah kerja Puskesmas Pekan Labuhan Medan ada yang belum sesuai dengan pedoman pengobatan dasar di Puskesmas 2007 yang ditetapkan. Ketidaksesuaian itu meliputi jenis antibiotik dan kesesuaian indikasi pemberiannya.

\section{DAFTAR PUSTAKA}

Ansel, H.C. (2008). Pengantar Sediaan Farmasi. edisi IV. Alih bahasa Ibrahim, F. Jakarta: UI Press. Halaman 23.

Darmansjah, I. (2008). Penggunaan Antibiotik Pada Pasien Anak. Diakses pada 12 september 2017 dari http://indonesia.digitaljournals.org/index.p hp/idnmed/article/download/901/9oo.

Daulay, R.M. (1992). Kendala penanganan Infeksi Saluran Pernafasan Akut. Jakarta: Cermin Dunia Kedokteran. Halaman 8-10.

Depkes RI. (2000). Informasi Tentang ISPA pada Balita. Jakarta: Pusat Penyuluhan Kesehatan Masyarakat. Halaman 15-16.

Effendi. (2009). Managemen Pusat Kesehatan Masyarakat. Jakarta: Salemba Medika. Halaman 28-31.

Gan, V.S.H., dan Istiantoro, Y.H. (2007). Penisilin, Sefalosporin dan Antibiotik Betalaktam lainnya, dalam Gunawan,S.G., Setiabudy, R., Nafrialdy, dan Elusabeth. nFarmakologi dan Terapi. Jakarta: Bagian Farmakologi Fakultas Kedokteran Universitas Indonesia. Halaman 667, 678, 681. 
BioLink, Vol.5 (1) (2018): hal. 11-21

Hadi U. (2009). Resistensi Antibiotik. Dalam: Buku Ajar Ilmu Penyakit Dalam Edisi IV, Jilid III. Jakarta: Universitas Indonesia. 2206: Halaman 50-55.

Harmita dan Radji, M. (2008). Kepekaan Terhadap Antibiotik. Dalam Buku Ajar Analisis Hayati. Edisi.3.EGC. Jakarta: Universitas Indonesia.

Halaman. 1-5.

Kementrian Kesehatan RI. (2011). Keputusan Menteri Kesehatan Republik Indonesia no. 2406/menkes/PER/XII/2011 Tentang Pedoman Umum Penggunaan Antibiotik.

Muluki, M. (2003). Analisis Faktor Yang Berhubungan Dengan Terjadinya Penyakit ISPA di Puskesmas Palanro Kecamatan Mallusetasi Kabupaten Barru Tahun 2002 - 2003. Tesis. Program Pasca Sarjana FKM Universitas Hasanuddin.

Muttaqin, A. (2008). Buku Ajar: Asuhan Keperawatan Klien Dengan Gangguan
Sistem Pernafasan. Jakarta: Penerbit Salemba Medika. Halaman. 25-38.

Nelson. (2003). Ilmu Kesehatan Anak. Jakarta: EGC. Halaman 7-8.

Notoatmodjo, S. (2010). Metodologi Penelitian Kesehatan. Jakarta : Rienka Cipta. Halaman 73.

Suhandayani, I. (2007). Faktor - Faktor Yang Berhubungan Dengan Kejadian Ispa Pada Balita Di Puskesmas Pati I Kabupaten Pati Tahun 2006. Semarang: Skripsi Tidak dipublikasikan.

Tjay, T. H., dan Raharja K. (2007). Obat-obat Penting. Elex Media Komputindo, Jakarta: UI Press. Halaman. 15-30.

WHO. (2001). Chough and cold remedies for the treatment of acute respiratory infection in young children. Halaman 64. 